\title{
An Exploratory Study of Differences in Manufacturing Strategy between National and Global Production Firms
}

\author{
Andreas Größler \\ Institute for Management Research, Radboud University Nijmegen \\ P.O. Box 9108, 6500 HK Nijmegen, Netherlands \\ Tel: +31-24-361-6287Ｅ-mail: a.groessler@fm.ru.nl
}

Received: October 15, $2010 \quad$ Accepted: October 26, $2010 \quad$ doi:10.5430/jms.v1n1p47

\begin{abstract}
The purpose of this paper is to explore differences of the manufacturing strategy between plants that produce in a global manufacturing network and such plants that are part of local production only. Both groups of firms serve a worldwide market. As methodology, the paper uses statistical analyses, in particular difference and correlation tests, which are based on data from the fourth round of the International Manufacturing Strategy Survey (IMSS). Major findings are that the two groups of plants differ concerning their order winners, capabilities and performance. Both types of plants exist in substantial quantities within the sample. Based on these results, the paper puts forward a detailed research agenda of manufacturing strategies in international contexts.
\end{abstract}

Keywords: Manufacturing strategy, Globalization, Off-shoring, Exploratory study

\section{Introduction}

Potential advantages of global production are manifold: cost savings, access to local markets, easier adaptation to different cultures, global branding, and acquisition of knowledge. However, this study shows that within a large international sample of manufacturing firms from specific industries more companies choose to produce in only one country than companies that decide for global production - even though both groups claim to compete internationally. This article explores what differentiates the two groups of companies in terms of the constituents of manufacturing strategy on the plant level: order winning criteria, strategic priorities and capabilities within manufacturing, and operations' performance.

This exploratory comparison is relevant because it can be assumed that the degree of internationalization of production within a company and the manufacturing strategy pursued at the plant level are interrelated. In this sense, one can expect differences between plants that are part of an international production network and plants that are nationally producing goods. However, what exactly the nature of this difference is has not been investigated in the literature. Thus, the purpose of this paper is to identify and discuss differences in manufacturing strategy of global and national production firms.

The paper is structured as follows. In the next section, the literature is reviewed that deals with the internationalization of manufacturing. In the section thereafter, it is explained why manufacturing strategies are worthwhile to investigate with the perspective of global versus national production. In the fourth section, the methods used in the statistical analyses are presented together with the empirical sample that is used as a database. The results of the analyses are provided in section five. In the section after that, the results are discussed and implications for managing manufacturing companies are considered. The paper closes with an exposition of issues for further research, which is derived from the exploratory investigation.

\section{Literature Review: Manufacturing on a Global Scale}

The general strategy literature discusses globalization from a variety of perspectives. The overall-not surprising - result of these discussions is that a global strategy is required when relevant interdependencies exist between the competitive positions of firms in different countries and continents (Porter, 1980; Hout et al., 1982; Porter, 1986; Prahalad \& Doz, 1987; Ohmae, 1990). Mostly, studies in the field of international management argue from a market-based perspective of strategy, i.e. they focus on aspects external to the company. However, some attempts have been made to take a resource-based, internal perspective on the merits of becoming global (Collis, 1991; Carr, 1993), which links more directly to the field of manufacturing strategy and operations management. 
Although some doubts have been raised whether a field called "International Operations Management (IOM)" is necessary in principle (e.g., Whybark, 1997), this study follows Ghemawat's (2003) notion that manufacturing firms experience a "semi-global" environment. Most companies operate neither in a truly global environment without geographical or cultural borders and differences, nor can they function in isolation without any influences from extraterritorial factors. Because of the semi-global environment, additional strategic issues from the international aspects of business exist that need to be considered by manufacturing strategists.

Studies in IOM often focus on co-ordination issues of existing plants, location decisions, or specifics of outsourcing decisions (e.g., Mol et al., 2005; Henisz \& Delios, 2001; Pennings \& Sleuwaegen, 2000; Arnold, 2000; Hoffman \& Schniederjans, 1994; Porter, 1990); only rarely, total manufacturing network configurations are considered (Meijboom \& Vos, 1997). This article aims at addressing a combination of two major research areas identified by Roth et al. (1997; see also Prasad \& Babbar, 2000): 'strategic issues' and 'location and facilities'. Thus, this study investigates which manufacturing strategies are followed either when firms decide to produce locally (in the sense of producing just in their home country) for a global market, or when they decide to install production facilities globally.

According to the Upsalla Internationalization Model (Johanson \& Wiedersheim-Paul, 1975; Johanson \& Vahlne, 1990), the firms in these two groups would be in two different stages of their internationalization process. Firms that produce locally and sell globally are on stages 2 or 3 of this model, meaning exporting through either independent or dependent sales organisations in different countries (stage 1 symbolizes no exporting activities at all). Firms that produce and sell globally would be on stage 4 of this model, which is exactly defined as this combination of global production and sales activities. According to this model, over time companies would move from stage 2 to stage 4; thus, firms that are local producers today would eventually become global producers. A similarly staged approach is proposed by Innovation-Related Internationalization Models, although with a different conceptual background than the Upsalla Model (see Andersen, 1993, for a review).

There is further theoretical, anecdotal and empirical evidence that internationalization can be beneficial for manufacturing firms (Buckley \& Casson, 1976; Ohmae, 1985; Henisz, 2003; Doukas \& Lang, 2003). Various factors are considered important when making the decision to internationalize manufacturing (DuBois et al., 1993; MacCarthy \& Atthirawong, 2003). Cost savings appear to be the most commonly assumed effects; nevertheless, the importance of such savings has been doubted (Ferdows, 1997a; Vereecke \& de Meyer, 2006; Pitelis \& Verbeke, 2007). Ferdows (1997b) identifies two other major reasons for the set-up of factories in different countries: market proximity and access to technological expertise. Bartlett et al. (2004) distinguish three ways how firms can benefit from becoming international: exploiting cross-national differences in sourcing and market potential, exploiting economies of scale, and exploiting economies of scope. Nevertheless, the question remains, why even within a group of companies with related products and/or markets, some companies produce internationally, while others do not, and what differentiates these two types of companies with regard to their internal structure and strategies. In this sense, this paper addresses Prasad et al.'s (2001, 660) question, "what are the differences in international operations strategies employed by similar [...] organizations [...]?"

Dunning (1980) provides a well-known and general attempt to conceptualise bundles of criteria that lead companies to internationalise their production: the OLI concept (Ownership-Location-Internalization). In his "eclectic theory" of international production, he claims that foreign direct investments of firms depend (i) on the ownership of certain resources, (ii) on the availability of certain resources at specific locations, and (iii) on the benefits of internalizing these resources. Although rather comprehensive, the theory does only implicitly shed light on the question, what the differences are in terms of the manufacturing strategy employed between companies going or not going international. This paper describes such differences based on concepts from current discussions in the manufacturing strategy literature: strategic resources, strategic priorities and capabilities, and operations' performance indicators. Thus, it concentrates on an internal perspective of organisations, since there seem to lie the greatest issues concerning globalization (Bartlett \& Ghoshal, 1987). In contrast, issues of global supply chain configurations (Cagliano et al., 2008; Ettlie \& Sethuraman, 2002; Levy, 1995) or global purchasing and sourcing (Leonidou, 1999; Murray et al., 1995; Kotabe \& Swan, 1994; Ellram, 1991; Kotabe, 1990; Arnold, 1989) are discussed elsewhere.

As far as methodology is concerned, there have been case studies (e.g., DuBois et al., 1993), a Delphi study (MacCarthy \& Atthirawong, 2003) and formal models (e.g., Flaherty \& Raubitschek, 1990) addressing the question, why some manufacturing firms produce on a global scale, while others do not (and, for instance, choose for exporting their product offerings). This question has been discussed under the label "market entry mode" in the literature (Anderson \& Gatignon, 1986; Kim \& Hwang, 1992; Agarwal \& Ramaswami, 1992). The issue is non-trivial because apparently both types of companies can be successful internationally. To shed some further light on this issue, Kalfadellis \& Gray (2002) call for 
survey based research of managerial perceptions as in this paper. Meijboom \& Vos (1997) ask for dynamic analyses due to the importance of the timing of the internationalization decision (Prasad et al., 2001, ask for investigating "time lags"; for a conceptual discussion of different stages see Anderson et al., 1998; for a first simulation attempt using complex adaptive systems see Slepniov \& Waehrens, 2008).

\section{Research Design: Manufacturing Strategy and the Globalization Decision}

Since no well-elaborated theory on the manufacturing strategy component of the internationalization decision exists, this study is not testing a theory but collecting exploratory evidence to formulate such a theory. While following an internal perspective, the general necessity to reconcile organisational assets with external competitive factors is not doubted. Rather, the paper focuses on that part of the "story" that is regularly not in the centre of the discussion: it investigates and cautiously interprets differences between national and global manufacturing firms concerning their manufacturing strategy. There is no claim made that firms manufacture globally because of the manufacturing strategy they pursue. Frequently, the motivation and the reasons for going global might be external pressures or issues of the size or supply chain organisation of the firms (as formulated in the 'eclectic model'; Dunning, 1980), with manufacturing strategy only being a resultant of these factors. Nevertheless, it appears relevant to know about differences in manufacturing strategy, since the comparison provides information about what operations actually does in manufacturing firms.

To elaborate on this last point, the decision to produce globally is mostly not driven by manufacturing strategy; rather manufacturing strategy is shaped by this decision, in particular on the level of individual plants. Thus, a strong effect can be supposed from the globalization decision to the actual manufacturing strategies pursued in the plants of a company. One reason for this is that the decision to globalize is taken on a corporate level while the manufacturing strategy has a strong plant-level manifestation (for a discussion of different strategy levels, see Gupta \& Lonial, 1998). The question therefore is how manufacturing strategies subsequently differ between plants being part of a national production company and plants being part of a global production network. From this starting point, related questions result, like, why differences can be observed, and how these differences can be interpreted. From an international management point of view, the interest in the answers to these questions lies in the fact that manufacturing strategies are an artefact of the reasons that initially have determined the globalization decision, i.e. they reflect the original intentions.

In contrast to this, the effect of manufacturing strategy on the globalization decision is rather weak, since mostly strategic issues outside the realm of manufacturing are being considered crucial when making the decision to globalize production. However, an influence from manufacturing strategy cannot completely be ignored, for instance when a well-articulated manufacturing strategy on the corporate level exists or when an existing off-shore plant is bought just because of its manufacturing strategy.

While these effects might occur only occasionally, it appears justified to claim that the success of globalization decisions depend - at least to a substantial share — on the manufacturing strategy that affected plants pursue. In the same way, a manufacturing strategy for a plant can only be successful when it corresponds to the globalization decision. Figure 1 reiterates the linkages between the decision to globalize production and manufacturing strategy on the plant level.

\section{$<$ Figure 1 about here $>$}

In summary, the manufacturing strategy of a plant shows the concrete effects of the decision to go global on the operations function and is of crucial importance to operations and production management as such. Thus, in the study differences in the manufacturing strategies of 'national' versus 'global' producers are compared.

Figure 2 depicts the research design of this study and what is understood when the term 'manufacturing strategy' is used. In an eclectic way, the following constructs are considered to represent manufacturing strategy: order winning criteria (Corbett \& Van Wassenhove, 1993; Hill, 2000), strategic priorities and capabilities within manufacturing (Ward et al., 1998; Boyer \& Lewis, 2002; Flynn \& Flynn, 2004; Größler \& Grübner, 2006), and operations' performance (De Toni \& Tonchia, 2001; Devaraj et al., 2004; Laugen et al., 2005). All constructs were operationalized in a well-tested questionnaire survey, as explained in the following section.

\section{$<$ Figure 2 about here $>$}

\section{Methodology and Data Sample: International Manufacturing Strategy Survey}

Empirical data is drawn from the fourth iteration of the International Manufacturing Strategy Survey (IMSS-4), which took place in 2005/2006 (Taylor \& Webster, 2006). In this international survey project, manufacturing plants from ISIC codes 28-35 are examined. These plants manufacture metal products, machinery, electrical devices, transportation equipment, and measuring and controlling equipment. More specifically, the directors of operations are asked since they appear to be the persons competent enough to answer the questions from the many domains of the participating plants 
that are covered in the questionnaire. Since in IMSS the level of analysis is the plant, manufacturing strategies of plants are compared in this study. Thus, it is examined how the decision to produce globally or nationally is reflected in the plants' strategy.

The following exploratory investigations are based on the collected data of 711 plants from 23 different countries. The response rate over all participating countries was about $30 \%$; sampling method was convenience sampling with some random participants. In order to enhance comparability within the study, 71 plants were omitted from the original IMSS-4 sample: plants with a substantial amount of missing values and plants with less than 100 employees have been excluded from further consideration, leaving 640 plants for the subsequent analysis. The table in Appendix A gives an indication of sample composition concerning industry and country affiliation of firms.

One goal of the IMSS project is to establish a longitudinal database of participating plants in order to study the dynamics of plant development. Therefore, the sample has been held constant as far as possible, which means that it has been tried to retain plants from previous rounds. However, because it was not possible to retain enough companies from earlier rounds (due to companies ceasing to exist, new corporate structures, or unwillingness to participate again), the IMSS-4 sample has been completed by random selection with a purposeful bias towards well performing plants. Because of this sampling strategy (preferring plants that have survived over some years or that are perceived as well performing), an overall bias towards high-achieving plants might be possible. Filling-out of the questionnaire took place in the participating companies, without influence of the researchers (self-administered study); questionnaires were sent out by mail, email or fax, frequently after establishing contact by telephone. Most questionnaire items are in the form of perceptual measures (Ketokivi \& Schroeder, 2004). For instance, respondents are asked to rate the internationality of competition on a five-point Likert scale.

Statistical methods used in this article are rather straightforward. In the beginning, plants are classified according to their degree of internationalization of manufacturing and competition. Later on, firms that claim to compete globally are further distinguished into those that appear to produce only locally (in their respective country) and those that produce globally. Differences between these two groups are explored with the help of t-tests.

\section{Results of Exploratory Analyses: Group Composition and Group Differences}

In the beginning of the analysis, for all companies of the IMSS sample the level of international production (using questionnaire item A3; all items can be found in Appendix B) and global sales (using item SC10c) have been put into relation (for a similar approach see Flaherty, 1996, chapter 1). A correlation analysis of the questionnaire values reveals a significant positive correlation between the two variables (A3 and SC10c). However, the effect size is rather small (Spearman's correlation coefficient, rho=0.08). So, at most, a weak tendency towards the "global competitor with global production" model can be stated.

In order to achieve clearer results, the companies in the sample were classified. Firms that reported to produce only at one site or only in the country of origin are considered "national manufacturers"; firms that produce in various countries in more than one continent are considered "global manufacturers". This approach excludes those companies that report to produce in a few countries but only in one continent. Thus, effects of economic regions spanning over continents (like the European Union) are prevented from having an impact on the analysis Further, this procedure increases the assumed differences between the two groups of companies, supposedly resulting in more and stronger outcomes of the statistical analyses. Forty-seven companies are kept out by this procedure.

For the geographical scale of competition, a questionnaire item is used that asks for the percentage of sales in the domestic market, in the same continent, and in different continents. Firms that only compete in the domestic market are named "national competitors"; firms responding with a share of more than $25 \%$ of their sales as going to different continents are called "global competitors". While this $25 \%$ limit is arbitrary (Cavusgil, 1982, uses for a somehow similar limit a $10 \%$ hurdle), it guarantees a substantial and frequent globalization of sales activities, which is an important factor in this study: only in very special cases will companies globalize their production, when they compete on a local market only. As with the scope of manufacturing, this approach excludes companies that are international to a certain degree (by selling to other countries in the same continent), but that are not truly global, i.e. having no or only a marginal share of sales in other continents (397 companies). After this classification, 232 firms remain in the database.

The classification employed here does not differentiate between a "multi-domestic" and a "global" orientation between companies in the sense of Shi \& Gregory (1998, p.203), since the data gives no indication whether a truly global strategy is followed or whether production and sales are "just" spread over many geographical regions. However, considering the other dimension in Shi and Gregory's framework, it can be stated that in this study "worldwide" and "multinational" plant dispersions are compared to "domestic" ones. 
In the reduced IMSS sample, more than 1/3 of companies are classified as "global manufacturers"; approximately $3 / 4$ of companies are categorised as "global competitors". Table 1 shows the number of manufacturing plants in the resulting four groups: while the ratio between national manufacturers and global manufacturers is approximately 4:3 for global competitors, it is $5: 1$ for national competitors.

Table 1 shows that the biggest amount of firms falls into the "national manufacturer/global competitor" category (called "inside-out", which can be thought of as globally exporting firms). The "distributed" group (global production and sales networks) comprises approximately the double number of firms as the "focused" group (firms restricted to their local market and production facilities). Only a small number of companies are classified as "outside-in", meaning they produce globally, but compete on a national market only (probably having off-shored parts of their production for cost reasons, but not competing in other markets).

\section{$<$ Table 1 about here $>$}

For the rest of the paper, only global competitors are considered (183 firms in total) because this is in accordance to the initial question, what differentiates companies that produce globally and such that do not in terms of manufacturing strategy, while both groups compete on a global level. Thus, in the following only the "distributed" (76 firms) and the "inside-out" group (107 firms) are compared. By leaving out the "national competitors", this study does not address the question whether firms should compete globally and whether a strong domestic position is supportive or inhibiting in this process (Porter, 1990; Baden-Fuller \& Stopford, 1991).

The first comparison (shown in Table 2) regards the environment in which these firms compete. T-tests on questionnaire items A4a to A4g show that "distributed" firms and the "inside-out" group do not differ a lot with respect to external factors. Significant differences can only be found for the geographical focus these firms have (item A4d): although both groups of companies compete globally, the group that manufactures globally reports a significantly higher level of internationalization concerning their environment than the firms that manufacture nationally. This questionnaire item asks in a general way about the geographical focus of a firm's business and is related to its overall activities, including manufacturing. In summary, firms in the "distributed" group seem to experience a more competitive environment than do firms in the "inside-out" group. However, with the exception reported, this finding is not statistically significant.

$<$ Table 2 about here $>$

The next comparison deals with differences in performance between the two groups of firms. In Table 3, financial (item A6) as well as manufacturing related (item B10) performance scores from the IMSS questionnaire are compared. For reasons of simplicity, only significant differences are reported. Concerning financial measures, companies with global manufacturing report higher performance scores than national manufacturers. This finding holds for absolute measures (sales revenue) as well as for relative measures (sales revenue, return on sales, and return on investment as compared to the major competitors of the firms). However, for sales revenue, this result can be an effect of the classification method, since the "inside-out" group comprise companies that consist of one plant only as compared to the "distributed" group, where the company necessarily consists of a network of plants (within different continents). It can be expected that firms with many plants most of the times have a higher sales volume than companies that have just one plant, i.e. the size of the company does matter in this respect. Thus, while the difference in absolute performance figures like sales revenue is rather intuitive, it has not been obvious beforehand that "distributed" firms are also doing slightly better in relative terms.

The relationship is just the opposite for one performance measure closer to manufacturing: throughput time efficiency is higher for the "inside-out" group than for the "distributed" group. All other manufacturing performance scores measured in IMSS do not show significant differences and are not consistent in the direction of differences.

$<$ Table 3 about here $>$

In Table 4, differences concerning the current order winning criteria of the firms are displayed (item A5; Hill, 2000). Five of in total eleven sub-items in the IMSS questionnaire show significant differences. Except for the order winner "product design and quality", global manufacturers put more emphasis on all other order winners. Design and quality, however, is more important to "inside-out" producers.

\section{$<$ Table 4 about here $>$}

The following analysis (Table 5) shows other constituents of manufacturing strategy. On the one hand, the change in importance of strategic priorities defined by the companies is compared (item B4). On the other hand, the intensities of strategic capabilities possessed by the firms are investigated (item B9). Thus, the analysis relates to the future and the current strategic assets with which the manufacturing function supports how companies compete in their markets (for a 
more detailed discussion about the differences between strategic priorities and strategic capabilities, see Größler \& Grübner, 2006; Ward et al., 1996; Roth, 1996).

$<$ Table 5 about here $>$

There is only one significant result for strategic priorities ("reducing time to market"): the "distributed" group identifies a shorter time to market as a stronger strategic priority. The two significant results for strategic capabilities do not indicate consistent differences between the groups. While the product customization ability has grown stronger in the "distributed" group than in the "inside-out" group, capacity utilization has improved stronger in the "inside-out" group than in the "distributed" group.

Some further analyses show that the "distributed" group involves suppliers significantly more in product development than the "inside-out" group ( $\mathrm{t}$-value $2.44, \mathrm{p}<0.05$ ), but that the contrary is true for the involvement of customers ( $\mathrm{t}$-value $1.79, \mathrm{p}<0.1$; item PD4). In addition, firms with global production have a significantly higher number of customers (on average 2740 compared to 440 ; these values become rather equal when normalized for the size of the company as represented by sales revenue; see Table 3 ). However, global producers consider only a smaller number (on average 31 compared to 42) as strategic customers, compared to national manufacturers (item SC5).

\section{Discussion and Practical Implications: Different Paths to Success}

As a result from the classification of companies can be stated that firms are able to compete globally, even when they have only national manufacturing. This finding is against a possibly naïve assumption that manufacturing should follow sales in its internationalization endeavours. However, the usefulness of going global with manufacturing depends presumably on the complexity of the products offered and the maturity of products. For instance, Sweeney (1994) describes that national producers could outsource substantial modules of their products to low-cost countries. This effect would bias the results of this analysis since such companies would appear as "inside-out" producers, when in fact only a small part of the value creation process is done locally. Although IMSS is not designed to detect differences between product characteristics that are below the ISIC level of classification, no statistical difference could be found between the two groups concerning the number and importance of suppliers. The difference that has been found (higher involvement of suppliers in product development for the "distributed" group) works contrary to the assumption that national producers"just" buy substantial parts of their product. In fact, suppliers are more involved for the global manufacturing group indicating a stronger linkage between them and their suppliers, as between national producers and their suppliers.

Global manufacturing firms experience a more intense environment than national manufacturers. However, the question cannot be answered with cross-sectional studies whether going global is a reaction on stronger competition or whether global manufacturing causes an increase in competition. Thus, the proverbial question after cause and effect is represented in the statistical results. The same holds for the differences in company size (based on sales revenue): it is not clear whether bigger firms (in terms of sales; see Table 3) more often decide to manufacture global, or whether firms that decide to manufacture globally become bigger.

Global manufacturers achieve better financial performance than national manufacturers, which is not true for manufacturing performance scores (see Table 3). For production throughput time, national manufacturers are better. When following a purely plant-focussed interpretation of the related questionnaire item (i.e. as percentage of real working time from first to last operation), this result probably can be interpreted in a way that local producers are more focussed, using their capacity to a higher degree. For a wider interpretation of total manufacturing lead time (from order reception to delivery), this result possibly can be interpreted by the fact that - when manufacturing sites are located in one country - transportation times during the production process are potentially shorter, than when production is distributed over continents. Thus, throughput time efficiency can be expected to be better for national producers in this case.

The manufacturing strategies of the two groups - represented in the strategic priorities and strategic capabilities of the firms - are not substantially different. The one difference for strategic priorities ("reducing time to market") can be loosely linked to the finding that throughput time efficiency is worse for global than for national manufacturers. A possible interpretation for this result would be that global manufacturers want to outweigh necessary under-performance concerning throughput time by being fast in bringing new products to the market (see Table 5).

The most pronounced differences between the two groups are to be found regarding the order winning criteria. The statistical analysis of the corresponding questionnaire items reveals why national manufacturers can be successful in global competition without producing globally: they simply offer products with superior quality and design. All other competitive factors presumably become of lower relevance, as long as products are excellent (and no other firms are 
able to produce the same quality products with additional benefits, like lower cost, or better after-sales service). While one could argue that for the industries in the sample (e.g., machinery and instrumentation), a high-quality strategy with strong local controls might make sense and is quite common, it is remarkable that it is obviously not the case for all companies in these industries. It is unclear at this point if in other industries internationalization decisions are made more consistently, i.e. whether in other industries a majority of companies go global (or stay local) when they compete globally. For instance, for high-volume consumer products it might be crucial to have a production site in the proximity of their worldwide markets, in order to reduce outbound transportation times.

The concentration of the "inside-out" group on product quality and design can be loosely connected to Simon's concept of what he calls 'hidden champions' (Simon, 1992; Simon, 2007; cf. also Fillis, 2001). In this view, 'hidden champions' are small or medium sized firms that are world market leaders, but — despite their success in the market place —are not widely known to the public (because they usually serve specialist markets for industry goods). Simon found out that these companies name product quality as the single most important factor for their success. 'Hidden champions' usually refrain from spreading their production and from outsourcing (for example, because of the availability of specific knowledge in their home region, the fear for infringements of their intellectual property, or the direct access of headquarters to production facilities). Although from the IMSS database it is unclear whether "inside-out" firms are market leaders, this group seems to follow at least a similar strategy as 'hidden champion' companies.

Strategically, a problem connected with the concentration on product quality is the dependence on the status quo. In other words, firms following this strategy need to be aware that the competitive setting might change and they should be willing to innovate and keep their product up-to-date, thus applying a dynamic perspective on product strategy. In contrast, when firms produce globally, they win orders on a few criteria other than product quality and design: product range, service, frequency of new products, and product innovation (see Table 4). Again, it is not clear from the analyses if this is a prerequisite of being global or if global production is a strategic move to become able to offer these order winners. However, Bartlett \& Ghoshal (1987) suggest that having multidimensional strategic capabilities is a need for globally acting companies.

The substantial differences in manufacturing strategy between the two groups of firms is an indication against a strict understanding of phased models of internationalization (Anderson, 1993) that suggest that companies naturally move along pre-defined stages in their degree of globalization. Although a longitudinal panel analysis would be necessary to determine ultimately the validity of these models for the industries investigated in this paper, it appears unlikely that plants are able to change their manufacturing strategy completely when moving from one to the other stage.

In summary, the statistical tests provide exploratory results for the differences in the manufacturing strategies of global and national producers. Consequently, there is no general clear-cut recommendation for firms, when they have to decide on the question, whether to manufacture globally or not and what manufacturing strategy to employ in either case. Besides the fact that in strategy general solutions ("one size fits all") should be treated with caution anyhow (Barabba et al., 2002), the analyses show that both types of firms can be successful (with only marginal, but significant benefits for global manufacturers). In addition, the results suggest that, when a firm manufactures a product that is unrivalled in its quality and/or design, it might be preferable for such a company to concentrate manufacturing on its home "turf", thus, producing where they are familiar with culture, worker attitudes, education, and skills, and with legislation and taxation regulations. Following this line of reasoning, going global with manufacturing might be a reaction of companies that do not possess such a superior product: in this case, they have to compete on price, on service, and on innovation, which might be triggered and supported by producing in different markets and cultures. Cautiously interpreting the differences in performance between the two groups of companies, the globalisation strategy seems to pay off for the "distributed" group.

\section{Further Research: Theory Building and Testing}

This study is exploratory in the sense that it does not test hypotheses about prevalent reasons for becoming a global or a national producer. Rather, this paper uses a big international database of manufacturing plants to explore some conceivable differences between the groups, with an emphasis on the manufacturing strategy pursued by the firms. By this means, the paper contributes to developing and eventually formulating a theory about globalizing production. A research agenda supporting this process of theory building and testing should comprise:

- the formulation of testable hypotheses, based on further analyses of IMSS data and on other databases, why some firms decide to produce globally, while others stay national with their production, when both types of firms compete on a global scale;

- the inclusion of information about other forms of vertical and horizontal integration, which are not tested in IMSS and which might have an effect on the globalization decision (for instance, the production in geographical in 
clusters; Nassembini, 2003);

- a further investigation of the dependency on industry factors and product characteristics like complexity and maturity (Sweeney, 1994);

- $\quad$ studying the role of changing economic conditions around the globe (for instance, higher average wages in former "low-cost" countries, costs of transportation; Goel et al., 2008);

- longitudinal research (for instance, over all IMSS rounds that have been conducted so far), in order to shed some light on the various cause and effect problems identified in this paper and in particular on changes in the manufacturing strategy when going global (De Toni et al., 1992; Andersen, 1993);

- a differential investigation of manufacturing companies going global from industrialized countries as compared to firms originating in developing countries and globalizing from there (Fleury \& Fleury, 2008);

- a differential investigation of the manufacturing strategies of factories serving specific roles in a manufacturing network (Shi \& Gregory, 1998; Vereecke \& Van Dierdonck, 2002; Vereecke et al., 2006; Vereecke et al., 2008);

- the causal mapping of factors and effects could contribute to a more comprehensive understanding of the globalization process;

- the formulation of dynamic models of going global can help investigating timing effects in this process, which are supposed to be crucial (Meijboom \& Vos, 1997; for a conceptual attempt see Johanson \& Vahlne, 1990).

One of the most pressing issues on the methodological side seems to be the inclusion of the notion of feedback. By utilizing longitudinal research designs and the formulation of formal models that explicitly take into account feedback relationships, questions can be investigated, like whether global manufacturers react to an intensified competition or whether they themselves create a more hostile environment by their move to global production.

\section{References}

Agarwal, S. \& Ramaswami, S.N. (1992). Choice of Foreign Market Entry Mode: Impact of Ownership, Location, and Internationalization Factors. Journal of International Business Studies, First Quarter, 1-27.

Andersen, O. (1993). On the Internationalization Process of Firms: A Critical Analysis. Journal of International Business Studies, Second Quarter, 209-231.

Anderson, E. \& Gatignon, H. (1986). Modes of Foreign Entry: A Transaction Cost Analysis and Propositions. Journal of International Business Studies, Fall, 1-26.

Anderson, V., Graham, S. \& Lawrence, P. (1998). Learning to Internationalize. Journal of Management Development, 17(7), 492-502.

Arnold, U. (1989). Global Sourcing - an Indispensible Element in Worldwide Competition. Management International Review, 29(4), 14-28.

Arnold, U. (2000). New Dimensions of Outsourcing - a Combination of Transaction Cost Economics and the Core Competencies Concept. European Journal of Purchasing and Supply Management, 6, 23-29.

Baden-Fuller, C. \& Stopford, J.M. (1991). Globalization Frustrated: The Case of White Goods. Strategic Management Journal, 12, 493-507.

Barabba, V., Pourdehnad, J. \& Ackoff, R.L. (2002). On Misdirecting Management. Strategy and Leadership, 30(5), 5-9.

Bartlett, C. \& Ghoshal, S. (1975). Managing across Borders: New Strategic Requirements. Sloan Management Review, 28(4), 7-17.

Bartlett, C., Ghoshal, S. \& Birkinshaw, J. (2004). Transnational Management. Boston: McGraw-Hill.

Boyer, K.K. \& Lewis, M.W. (2002). Competitive Priorities: Investigating the Need for Trade-offs in Operations Strategy. Journal of Operations Management, 11(1), 9-20.

Buckley, P.J. \& Casson, M. (1976). The Future of the Multinational Enterprise. London: Macmillan.

Cagliano, R., Golini, R., Caniato, F., Kalchschmidt, M. \& Spina, G. (2008). Supply Chain Configurations in a Global Environment: A Longitudinal Perspective. In European Operations Management Association (ed.): EurOMA 2008 Conference Proceedings, Groningen.

Carr, C. (1993). Global, National and Resource-based Strategies: An Examination of Strategic Choice and Performance in the Vehicle Components Industry. Strategic Management Journal, 14, 551-568. 
Cavusgil, S.T. (1982). Some Observations on the Relevance of Critical Variables for Internationalization Stages. In Czinkota, M.R. \& Tesar, G. (ed.), Export Management: An International Context. New York: Praeger.

Collis, D.J. (1991). A Resource-based Analysis of Global Competition: The Case of the Bearings Industry. Strategic Management Journal, 12, 49-68.

Corbett, C. \& Van Wassenhove, L. (1993). Trade-offs: What Trade-offs: Competence and Competitiveness in Manufacturing Strategy. California Management Review, 35(4), 107-122.

De Toni, A. \& Tonchia, S. (2001). Performance Measurement Systems. International Journal of Operations and Production Management, 21(1-2), 46-70.

De Toni, A., Filippini, R. \& Sforza, C. (1992). Manufacturing Strategy in Global Markets: An Operations Management Model. International Journal of Operations and Production Management, 12(4), 7-18.

Devaraj, S., Hollingworth, D.G. \& Schroeder, R.G. (2004). Generic Manufacturing Strategies and Plant Performance. Journal of Operations Management, 22, 313-333.

Doukas, J.A. \& Lang, L.H.P. (2003). Foreign Direct Investment, Diversification and Firm Performance. Journal of International Business Studies, 34(2), 153-172.

DuBois, F.L., Toyne, B. \& Oliff, M.D. (1993). International Manufacturing Strategies of U.S. Multinationals: A Conceptual Framework Based on a Four-Industry Study. Journal of International Business Studies, 24(2), 307-333.

Dunning, J.H. (1980). Toward an Eclectic Theory of International Production: Some Empirical Tests. Journal of International Business Studies, 11(1), 9-31.

Ellram, L.M. (1991). Key Success Factors and Barriers in International Purchasing Partnerships. Management Decision, 29(7), 38-44.

Etlie, J.E. \& Sethuraman, K. (2002). Locus of Supply and Global Manufacturing. International Journal of Operations and Production Management, 22(3), 349-370.

Ferdows, K. (1997a). Made in the World: The Global Spread of Production. Production and Operations Management, 6(2), 102-109.

Ferdows, K. (1997b). Making the Most of Foreign Factories. Harvard Business Review, 75(2), 73-88.

Fillis, I. (2001). Small Firm Internationalisation: an Investigative Survey and Future Research Directions. Management Decision, 39(9), 767-783.

Flaherty, M.T. \& Raubitschek, R.S. (1990). Local Presence and International Manufacturing Configurations in Technology-Intensive Industries. Japan and the World Economy, 2(4), 301-326.

Flaherty, M.T. (1996). Global Operations Management. New York: McGraw-Hill.

Fleury, A. \& Fleury, M.T.L. (2008). The Role of Manufacturing in the Internationalisation Strategies of Firms from Emergent Economies. In European Operations Management Association (ed.): EurOMA 2008 Conference Proceedings, Groningen.

Flynn, B.B. \& Flynn, E.J. (2004). An Exploratory Study of the Nature of Cumulative Capabilities. Journal of Operations Management, 22(5), 439-457.

Ghemawat, P. (2003). Semiglobalization and International Business Strategy. Journal of International Business Studies, 34(2), 138-152.

Goel, A., Moussavi, N. \& Srivatsan, V.N. (2008). Time to Rethink Offshoring? McKinsey Quarterly, September 2008, $1-5$.

Größler, A. \& Grübner, A. (2006). An Empirical Model of the Relationships between Manufacturing Capabilities. International Journal of Operations and Production Management, 26(5), 458-485.

Gupta, Y.P. \& Lonial, S.C. (1998). Exploring Linkages between Manufacturing Strategy, Business Strategy, and Organizational Strategy. Production and Operations Management, 7(3), 243-264.

Henisz, W.J. \& Delios, A. (2001). Uncertainty, Imitation, and Plant Location: Japanese Multinational Corporations, 1990-1996. Administrative Science Quarterly, 46(3), 443-475.

Henisz, W.J. (2003). The Power of the Buckley and Casson Thesis: the Ability to Manage Institutional Idiosyncrasies. Journal of International Business Studies, 34(2), 173-184. 
Hill, T. (2000). Manufacturing Strategy - Text and Cases ( $2^{\text {nd }}$ edition). Basingstoke: Palgrave.

Hoffman, J.J. \& Schniederjans, M.J. (1994). A Two-Stage Model for Structuring Global Facility Site Selection Decisions. International Journal of Operations and Production Management, 14(4), 79-96.

Hout, T., Porter, M.E. \& Rudden, E. (1982). How Global Companies Win Out. Harvard Business Review, 60(5), 98-109.

Johanson, J. \& Vahlne, J.-E. (1990). The Mechanism of Internationalization. International Marketing Review, 7(4), $11-24$.

Johanson, J. \& Wiedersheim-Paul, F. (1975). The Internationalization of the Firm - Four Swedish Cases. Journal of Management Studies, 12(3), 305-323.

Kalfadellis, P. \& Gray, J. (2002). Are Proxies Valid Measures of Internalisation? Paper presented at the $28^{\text {th }}$ European International Business Academy Conference, Athens, Greece.

Ketokivi, M.A. \& Schroeder, R.G. (2004). Perceptual Measures of Performance: Fact or Fiction? Journal of Operations Management, 22(3), 247-264.

Kim, W.C. \& Hwang, P. (1992). Global Strategy and Multinationals' Entry Mode Choice. Journal of International Business Studies, First Quarter, 29-53.

Kotabe, M. \& Swan, K.S. (1994). Offshore Sourcing: Reaction, Maturation, and Consolidation of U.S. Multinationals. Journal of International Business Studies, 25(1), 115-140.

Kotabe, M. (1990). The Relationship of Offshore Sourcing and Innovativeness of U.S. Multinational Firms: an Empirical Investigation. Journal of International Business Studies, 21(4), 623-638.

Laugen, B.T., Acur, N., Boer, H. \& Frick, J. (2005). Best Manufacturing Practices: What Do the Best-Performing Companies Do? International Journal of Operations and Production Management, 25(2), 131-150.

Leonidou, L.C. (1999). Barriers to International Purchasing: the Relevance of Firm Characteristics. International Business Review, 8, 487-512.

Levy, D.L. (1995). International Sourcing and Supply Chain Stability. Journal of International Business Studies, 26(2), 343-360.

MacCarthy, B.L. \& Atthirawong, W. (2003). Factors Affecting Location Decisions in International Operations - a Delphi study. International Journal of Operations and Production Management, 23(7), 794-818.

Meijboom, B. \& Vos, B. (1997). International Manufacturing and Location Decisions: Balancing configuration and co-ordination aspects. International Journal of Operations and Production Management, 17(8), 790-805.

Mol, M.J., van Tulder, R.J.M. \& Beije, P.R. (2005). Antecedents and Performance Consequences of International Outsourcing. International Business Review, 14, 599-617.

Murray, J.Y., Wildt, A.R. \& Kotabe, M. (1995). Global Sourcing Strategies of U.S. Subsidiaries of Foreign Multinationals. Management International Review, 35(4), 307-324.

Nassimbeni, G. (2003). Local Manufacturing Systems and Global Economy: Are They Compatible? - the case of the Italian eyewear district. Journal of Operations Management, 21(2), 151 - 171.

Ohmae, K. (1985). Triad Power: The Coming Shape of Global Competition. London: Macmillan.

Ohmae, K. (1990). The Borderless World: Power and Strategy in the Interlocked Economy. New York: Harper Business.

Pennings, E. \& Sleuwaegen, L. (2000). International Relocation: Firm and Industry Determinants. Economics Letters, 67, 179-186.

Pitelis, C. \& Verbeke, A. (2007). Edith Penrose and the Future of the Multinational Enterprise: New research directions. Management International Review, 47(2), 139-149.

Porter, M.E. (1980). Competitive Strategy: Techniques for Analyzing Industries and Competitors. New York: Free Press.

Porter, M.E. (1986). Competition in Global Industries: A Conceptual Framework. In Porter, M.E. (Ed.), Competition in Global Industries. New York: Free Press.

Porter, M.E. (1990). The Competitive Advantage of Nations. New York: Macmillan.

Prahalad, C.K. \& Doz, Y.L. (1987). The Multinational Mission: Balancing Local Demand and Global Vision. New York: Free Press. 
Prasad, S. \& Babbar, S. (2000). International Operations Management Research. Journal of Operations Management, 18(2), 209-247.

Prasad, S., Babbar, S. \& Motwani, J. (2001). International Operations Strategy: Current Efforts and Future Directions. International Journal of Operations and Production Management, 21(5-6), 645-665.

Roth, A.V. (1996). Competitive Progression Theory: Explanation and Evidence. In Voss, C.A. (ed.), Manufacturing Strategy, $3^{\text {rd }}$ International Conference of the EurOMA, London, 563-568.

Roth, A.V., Gray, A.E., Singhal, J. \& Singhal, K. (1997). International Technology and Operations Management: Resource toolkit for research and teaching. Production and Operations Management, 6(2), 167-187.

Shi, Y. \& Gregory, M. (1998). International Manufacturing Networks - to Develop Global Competitive Capabilities. Journal of Operations Management, 16, 195-214.

Simon, H. (1992). Lessons from Germany‘s Midsize Giants. Harvard Business Review, March/April, 115-123.

Simon, H. (2007). Hidden Champions des 21. Jahrhunderts. Frankfurt: Campus.

Slepniov, D. \& Waehrens, B.V. (2008). Evolving Interdependencies in the Context of Global Operations. In European Operations Management Association (ed.): EurOMA 2008 Conference Proceedings, Groningen.

Sweeney, M.T. (1994). A Methodology for the Strategic Management of International Manufacturing and Sourcing. The International Journal of Logistics Management, 5(1), 55-65.

Taylor, A. \& Webster, M. (2006). Editorial. International Journal of Operations and Production Management, 26(3), 228-231.

Vereecke, A. \& De Meyer, A. (2006). Do Not Forget the Strategic Architecture of Your Manufacturing Network While Offshoring. Vlerick Leuven Gent Working Paper Series, No. 2006/12.

Vereecke, A., \& Van Dierdonck, R. (2002). The Strategic Role of the Plant: Testing Ferdow's Model. International Journal of Operations and Production Management, 22, 492-514.

Vereecke, A., De Meyer, A., \& Van Dierdonck, R. (2008). The Strategic Role of the Plant in International Networks: A Longitudinal Study. In European Operations Management Association (ed.): EurOMA 2008 Conference Proceedings, Groningen.

Vereecke, A., Van Dierdonck, R., \& De Meyer, A. (2006). A Typology of Plants in Global Manufacturing Networks. Management Science, 52, 1737-1750.

Ward, P.T., Bickford, D.J. \& Leong, G.K. (1996). Configurations of Manufacturing Strategy, Business Strategy, Environment and Structure. Journal of Management, 22(4), 597-626.

Ward, P.T., McCreery, J.K., Ritzman, L.P. \& Sharma, D. (1998). Competitive Priorities in Operations Management. Decision Sciences, 29(4), 1035-1046.

Whybark, D.C. (1997). Does International Operations Management Need a Separate Perspective? Production and Operations Management, 6(2), 122-130. 
Appendix A. IMSS-4 sample composition (ten companies did not report on industry and are therefore not included in the table)

\begin{tabular}{|c|c|c|c|c|c|c|c|c|c|}
\hline & \multicolumn{8}{|c|}{ ISIC Code Rev. 3.1} & \multirow[t]{2}{*}{ Total } \\
\hline Country & $\begin{array}{c}28 \\
\text { (fabricated } \\
\text { metal } \\
\text { products) } \\
\end{array}$ & $\begin{array}{c}29 \\
\text { (machinery } \\
\& \\
\text { equipment) } \\
\end{array}$ & $\begin{array}{c}30 \\
\text { (office \& } \\
\text { automation } \\
\text { machinery) }\end{array}$ & $\begin{array}{c}31 \\
\text { (electrical } \\
\text { machinery) }\end{array}$ & $\begin{array}{c}32 \\
\text { (radio, TV, } \\
\text { communication } \\
\text { equipment) }\end{array}$ & $\begin{array}{c}33 \\
\text { (medical \& } \\
\text { optical } \\
\text { instruments) } \\
\end{array}$ & $\begin{array}{c}34 \\
\text { (motor } \\
\text { vehicles \& } \\
\text { trailers) } \\
\end{array}$ & $\begin{array}{c}35 \\
\text { (transport } \\
\text { equipment) }\end{array}$ & \\
\hline Argentina & 24 & 6 & 1 & 5 & 1 & 1 & 5 & 1 & 44 \\
\hline Australia & 3 & 2 & 0 & 0 & 0 & 0 & 0 & 0 & 5 \\
\hline Belgium & 15 & 4 & 0 & 4 & 3 & 0 & 1 & 3 & 30 \\
\hline Brazil & 5 & 3 & 0 & 0 & 1 & 0 & 5 & 1 & 15 \\
\hline Canada & 12 & 6 & 0 & 1 & 1 & 0 & 3 & 1 & 24 \\
\hline China & 7 & 9 & 2 & 12 & 2 & 0 & 3 & 0 & 35 \\
\hline Denmark & 10 & 8 & 1 & 6 & 2 & 4 & 0 & 1 & 32 \\
\hline Estonia & 6 & 3 & 3 & 6 & 1 & 0 & 0 & 0 & 19 \\
\hline Germany & 6 & 2 & 0 & 4 & 1 & 2 & 0 & 1 & 16 \\
\hline Greece & 5 & 1 & 0 & 1 & 1 & 0 & 0 & 0 & 8 \\
\hline Hungary & 22 & 9 & 0 & 4 & 6 & 1 & 9 & 3 & 54 \\
\hline Ireland & 2 & 2 & 0 & 4 & 3 & 2 & 0 & 0 & 13 \\
\hline Israel & 7 & 1 & 1 & 1 & 1 & 0 & 0 & 0 & 11 \\
\hline Italy & 8 & 19 & 0 & 4 & 7 & 1 & 2 & 4 & 45 \\
\hline $\begin{array}{c}\text { New } \\
\text { Zealand }\end{array}$ & 7 & 8 & 0 & 4 & 0 & 0 & 0 & 1 & 20 \\
\hline Norway & 10 & 1 & 0 & 2 & 0 & 1 & 1 & 0 & 15 \\
\hline Portugal & 6 & 1 & 0 & 1 & 0 & 0 & 1 & 0 & 9 \\
\hline Sweden & 24 & 20 & 0 & 9 & 4 & 4 & 12 & 5 & 78 \\
\hline $\begin{array}{c}\text { The } \\
\text { Netherlan } \\
\text { ds }\end{array}$ & 18 & 11 & 4 & 13 & 0 & 5 & 3 & 5 & 59 \\
\hline Turkey & 5 & 12 & 0 & 2 & 1 & 0 & 9 & 5 & 34 \\
\hline $\begin{array}{c}\text { United } \\
\text { Kingdom }\end{array}$ & 5 & 1 & 0 & 3 & 0 & 0 & 1 & 1 & 11 \\
\hline USA & 13 & 0 & 3 & 1 & 1 & 2 & 4 & 7 & 31 \\
\hline $\begin{array}{c}\text { Venezuel } \\
\mathrm{a}\end{array}$ & 14 & 0 & 0 & 2 & 0 & 0 & 6 & 0 & 22 \\
\hline Total & 234 & 129 & 15 & 89 & 36 & 23 & 65 & 39 & 630 \\
\hline
\end{tabular}

Appendix B. Original items from IMSS-4 questionnaire used in this study

A3. Which best describes your business unit's situation relating to manufacturing?

$\begin{array}{cccc}\begin{array}{c}\text { At one site in this } \\ \text { country }\end{array} & \begin{array}{c}\text { At more than one } \\ \text { site in this } \\ \text { country }\end{array} & \begin{array}{c}\text { At sites in a few } \\ \text { countries in this } \\ \text { continent* }\end{array} & \begin{array}{c}\text { Globally, at sites } \\ \text { in various } \\ \text { continents }\end{array}\end{array}$

Where are the business unit's products produced?

SC10. Regarding location of your sales activity, indicate the approximate split of sales according to the following (your answers should add up to $100 \%$ ):

Sales activity
a) This country

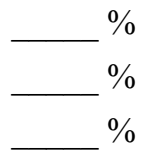
b) Within your continent*
c) Outside your continent*
$100 \%$ 
A4. How would you describe the external environment?
a) Market dynamics
Declining rapidly
Few segments
b) Market span
Physical attributes
c) Product focus
National
d) Geographical focus
Low intensity
e) Competition intensity
Few competitors
Closed to new players

$\begin{array}{lllll}1 & 2 & 3 & 4 & 5 \\ 1 & 2 & 3 & 4 & 5 \\ 1 & 2 & 3 & 4 & 5 \\ 1 & 2 & 3 & 4 & 5 \\ 1 & 2 & 3 & 4 & 5 \\ 1 & 2 & 3 & 4 & 5 \\ 1 & 2 & 3 & 4 & 5\end{array}$
Growing rapidly
Many segments
Service emphasis
International
High intensity
Many competitors
g) Market entry

A6. What is the current business unit performance? For market share indicate average in market(s) served by business unit products. How do you perform relative to three years ago and to main competitor(s)*?

\begin{tabular}{|c|c|c|c|c|c|c|c|c|c|c|c|c|}
\hline & \multirow{3}{*}{$\begin{array}{l}\text { Current } \\
\text { figure } \\
(2004)\end{array}$} & \multicolumn{6}{|c|}{ Compared to three years ago the indicator has } & \multirow{2}{*}{\multicolumn{5}{|c|}{$\begin{array}{l}\text { Relative to our main } \\
\text { competitor(s), our } \\
\text { performance is }\end{array}$}} \\
\hline & & \multirow{2}{*}{\multicolumn{2}{|c|}{$\begin{array}{c}\text { deteriorated } \\
\text { more than } \\
10 \%\end{array}$}} & \multirow{2}{*}{$\begin{array}{c}\text { stayed } \\
\text { about } \\
\text { the } \\
\text { same }\end{array}$} & \multirow{2}{*}{$\begin{array}{c}\text { improv } \\
\text { ed } \\
10 \%-3 \\
0 \%\end{array}$} & \multirow{2}{*}{$\begin{array}{c}\text { impr } \\
\text { oved } \\
30 \%- \\
50 \%\end{array}$} & \multirow{2}{*}{$\begin{array}{c}\text { improv } \\
\text { ed } \\
\text { more } \\
\text { than } \\
\mathbf{5 0 \%}\end{array}$} & & & & & \\
\hline & & & & & & & & $\begin{array}{l}\text { much } \\
\text { worse }\end{array}$ & & equal & & \\
\hline Sales & & $\epsilon$ & 1 & 2 & 3 & 4 & 5 & 1 & 2 & 3 & 4 & 5 \\
\hline Market share & & $\%$ & 1 & 2 & 3 & 4 & 5 & 1 & 2 & 3 & 4 & 5 \\
\hline Return on sales (ROS) & & $\%$ & 1 & 2 & 3 & 4 & 5 & 1 & 2 & 3 & 4 & 5 \\
\hline $\begin{array}{l}\text { Return on investment } \\
\text { (ROI) }\end{array}$ & & $\%$ & 1 & 2 & 3 & 4 & 5 & 1 & 2 & 3 & 4 & 5 \\
\hline
\end{tabular}

1 ROS $=$ Earnings before interests and taxes/Sales 2 ROI = Earnings before interests and taxes/Total Assets

B10. What is the current performance level on the following dimensions?

Throughput Time Efficiency (defined as the time the products are worked on as a \% of the total manufacturing lead time - i.e. start of first operation to finish of last operation)?

Late deliveries to customers (as percentage of orders delivered)?

Scrap and rework costs (as percentage of sales)

Customer complaints (as percentage of orders delivered)

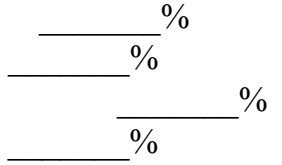

A5.Consider the importance of the following attributes to win orders from your major customers.

\begin{tabular}{|c|c|c|c|c|c|c|c|c|c|c|}
\hline \multirow[b]{3}{*}{ lower selling prices } & \multicolumn{5}{|c|}{ Current importance } & \multicolumn{5}{|c|}{ Over the last 3 years the goal has } \\
\hline & \multicolumn{2}{|c|}{$\begin{array}{l}\text { Not } \\
\text { important }\end{array}$} & & \multicolumn{2}{|c|}{$\begin{array}{r}\text { Very } \\
\text { important }\end{array}$} & \multicolumn{2}{|c|}{$\begin{array}{l}\text { become } \\
\text { less } \\
\text { important }\end{array}$} & \multirow{2}{*}{\begin{tabular}{|c}
$\begin{array}{c}\text { stayed } \\
\text { the } \\
\text { same }\end{array}$ \\
3
\end{tabular}} & \multicolumn{2}{|c|}{$\begin{array}{r}\text { become } \\
\text { more } \\
\text { important }\end{array}$} \\
\hline & 1 & 2 & 3 & 4 & 5 & 1 & 2 & & 4 & 5 \\
\hline superior product design and quality & 1 & 2 & 3 & 4 & 5 & 1 & 2 & 3 & 4 & 5 \\
\hline superior conformance quality & 1 & 2 & 3 & 4 & 5 & 1 & 2 & 3 & 4 & 5 \\
\hline more dependable deliveries & 1 & 2 & 3 & 4 & 5 & 1 & 2 & 3 & 4 & 5 \\
\hline faster deliveries & 1 & 2 & 3 & 4 & 5 & 1 & 2 & 3 & 4 & 5 \\
\hline $\begin{array}{c}\text { superior customer service } \text { (after-sales } \\
\text { and/or technical support) }\end{array}$ & 1 & 2 & 3 & 4 & 5 & 1 & 2 & 3 & 4 & 5 \\
\hline wider product range & 1 & 2 & 3 & 4 & 5 & 1 & 2 & 3 & 4 & 5 \\
\hline offer new products more frequently & 1 & 2 & 3 & 4 & 5 & 1 & 2 & 3 & 4 & 5 \\
\hline offer more innovative products & 1 & 2 & 3 & 4 & 5 & 1 & 2 & 3 & 4 & 5 \\
\hline greater order size flexibility & 1 & 2 & 3 & 4 & 5 & 1 & 2 & 3 & 4 & 5 \\
\hline environmentally sound products & 1 & 2 & 3 & 4 & 5 & 1 & 2 & 3 & 4 & 5 \\
\hline
\end{tabular}

B4. How important are the following improvement goals for your manufacturing function for the next 3 years?

Improving manufacturing conformance

Improving product quality and reliability

Increasing product customization ability

Increasing volume flexibility

Increasing mix flexibility
Not important

Very important

$\begin{array}{lllll}1 & 2 & 3 & 4 & 5 \\ 1 & 2 & 3 & 4 & 5 \\ 1 & 2 & 3 & 4 & 5 \\ 1 & 2 & 3 & 4 & 5 \\ 1 & 2 & 3 & 4 & 5\end{array}$




$\begin{array}{llllll}\text { Reducing time to market } & 1 & 2 & 3 & 4 & 5 \\ \text { Increasing product innovativeness } & 1 & 2 & 3 & 4 & 5 \\ \text { Improving customer service and support } & 1 & 2 & 3 & 4 & 5 \\ \text { Increasing delivery speed } & 1 & 2 & 3 & 4 & 5 \\ \text { Increasing delivery reliability } & 1 & 2 & 3 & 4 & 5 \\ \text { Reducing unit manufacturing cost } & 1 & 2 & 3 & 4 & 5 \\ \text { Reducing manufacturing lead time } & 1 & 2 & 3 & 4 & 5 \\ \text { Reducing procurement lead time } & 1 & 2 & 3 & 4 & 5 \\ \text { Reducing procurement costs } & 1 & 2 & 3 & 4 & 5 \\ \text { Increasing labour productivity } & 1 & 2 & 3 & 4 & 5 \\ \text { Increasing inventory turnover } & 1 & 2 & 3 & 4 & 5 \\ \text { Increasing capacity utilization } & 1 & 2 & 3 & 4 & 5 \\ \text { Reducing overhead costs } & 1 & 2 & 3 & 4 & 5 \\ \text { Improving employee satisfaction } & 1 & 2 & 3 & 4 & 5 \\ \text { Improving your environmental performance } & 1 & 2 & 3 & 4 & 5\end{array}$

B9. How has your operational performance changed over the last three years? How does your current performance compare with main competitor(s)*?

\begin{tabular}{|c|c|c|c|c|c|c|c|c|c|c|}
\hline & \multicolumn{5}{|c|}{$\begin{array}{l}\text { Compared to three years ago the indicator } \\
\text { has }\end{array}$} & \multirow{2}{*}{\multicolumn{5}{|c|}{$\begin{array}{c}\text { Relative to our main } \\
\text { competitor(s), our } \\
\text { performance is }\end{array}$}} \\
\hline & \multirow{2}{*}{$\begin{array}{c}\text { deteriora1 } \\
\text { ed more } \\
\text { than } 10 \%\end{array}$} & \multirow{2}{*}{$\begin{array}{l}\text { stayed } \\
\text { about } \\
\text { the same }\end{array}$} & \multirow{2}{*}{$\begin{array}{c}\text { improv } \\
\text { ed } \\
10 \%-3 \\
0 \%\end{array}$} & \multirow{2}{*}{$\begin{array}{c}\text { improv } \\
\text { ed } \\
30 \%-5 \\
0 \%\end{array}$} & \multirow{2}{*}{$\begin{array}{c}\text { improv } \\
\text { ed } \\
\text { more } \\
\text { than } \\
\mathbf{5 0 \%}\end{array}$} & & & & & \\
\hline & & & & & & $\begin{array}{l}\text { much } \\
\text { worse }\end{array}$ & & qual & & \\
\hline Manufacturing conformance & 1 & 2 & 3 & 4 & 5 & 1 & 2 & 3 & 4 & 5 \\
\hline Product quality and reliability & 1 & 2 & 3 & 4 & 5 & 1 & 2 & 3 & 4 & 5 \\
\hline Product customization ability & 1 & 2 & 3 & 4 & 5 & 1 & 2 & 3 & 4 & 5 \\
\hline Volume flexibility & 1 & 2 & 3 & 4 & 5 & 1 & 2 & 3 & 4 & 5 \\
\hline Mix flexibility & 1 & 2 & 3 & 4 & 5 & 1 & 2 & 3 & 4 & 5 \\
\hline Time to market & 1 & 2 & 3 & 4 & 5 & 1 & 2 & 3 & 4 & 5 \\
\hline Product innovativeness & 1 & 2 & 3 & 4 & 5 & 1 & 2 & 3 & 4 & 5 \\
\hline Customer service and support & 1 & 2 & 3 & 4 & 5 & 1 & 2 & 3 & 4 & 5 \\
\hline Delivery speed & 1 & 2 & 3 & 4 & 5 & 1 & 2 & 3 & 4 & 5 \\
\hline Delivery dependability & 1 & 2 & 3 & 4 & 5 & 1 & 2 & 3 & 4 & 5 \\
\hline Unit manufacturing cost & 1 & 2 & 3 & 4 & 5 & 1 & 2 & 3 & 4 & 5 \\
\hline Manufacturing lead time & 1 & 2 & 3 & 4 & 5 & 1 & 2 & 3 & 4 & 5 \\
\hline Procurement lead time & 1 & 2 & 3 & 4 & 5 & 1 & 2 & 3 & 4 & 5 \\
\hline Procurement costs & 1 & 2 & 3 & 4 & 5 & 1 & 2 & 3 & 4 & 5 \\
\hline Labour productivity & 1 & 2 & 3 & 4 & 5 & 1 & 2 & 3 & 4 & 5 \\
\hline Inventory turnover & 1 & 2 & 3 & 4 & 5 & 1 & 2 & 3 & 4 & 5 \\
\hline Capacity utilization & 1 & 2 & 3 & 4 & 5 & 1 & 2 & 3 & 4 & 5 \\
\hline Overhead costs & 1 & 2 & 3 & 4 & 5 & 1 & 2 & 3 & 4 & 5 \\
\hline Employee satisfaction & 1 & 2 & 3 & 4 & 5 & 1 & 2 & 3 & 4 & 5 \\
\hline Environmental performance & 1 & 2 & 3 & 4 & 5 & 1 & 2 & 3 & 4 & 5 \\
\hline
\end{tabular}

*consider the average performance of the group of competitors that are the direct benchmark for the plant 
PD4. To what extent do the following stakeholders collaborate with the R\&D function in your product development process?

\section{Suppliers \\ Manufacturing \\ Marketing \\ Customers}

\begin{tabular}{ccccc}
\multicolumn{2}{c}{ No collaboration } & \multicolumn{2}{c}{ High collaboration } \\
\hline 1 & 2 & 3 & 4 & 5 \\
1 & 2 & 3 & 4 & 5 \\
1 & 2 & 3 & 4 & 5 \\
1 & 2 & 3 & 4 & 5
\end{tabular}

SC5. Indicate the following supplier figures:

Total number of suppliers

(figure for 2004)
Average number of suppliers per item
Proportion of suppliers considered as key/strategic suppliers

Table 1. Classification of companies (percentages in relation to the total sample size of 640 companies)

\begin{tabular}{|c|c|c|c|}
\hline & $\begin{array}{c}\text { National } \\
\text { Competitors }\end{array}$ & $\begin{array}{c}\text { Global } \\
\text { Competitors }\end{array}$ & Total \\
\hline National Manufacturers & $\begin{array}{c}41 \\
\text { focused } \\
(6.4 \%)\end{array}$ & $\begin{array}{c}107 \\
\text { inside-out } \\
(16.7 \%)\end{array}$ & $\begin{array}{c}148 \\
(23.1 \%)\end{array}$ \\
\hline Global Manufacturers & $\begin{array}{c}\mathbf{8} \\
\text { outside-in } \\
(1.3 \%) \\
\end{array}$ & $\begin{array}{c}\mathbf{7 6} \\
\text { distributed } \\
(11.9 \%) \\
\end{array}$ & $\begin{array}{c}84 \\
(13.2 \%)\end{array}$ \\
\hline Total & $\begin{array}{c}49 \\
(7.7 \%)\end{array}$ & $\begin{array}{c}183 \\
(28.6 \%)\end{array}$ & $\begin{array}{c}232 \\
(36.3 \%)\end{array}$ \\
\hline
\end{tabular}

Table 2. Differences concerning environment $(* \mathrm{p}<0.05)$

\begin{tabular}{|l|c|c|c|}
\hline & $\begin{array}{c}\text { Inside-out } \\
\text { (average) }\end{array}$ & $\begin{array}{c}\text { Distributed } \\
\text { (average) }\end{array}$ & T-value \\
\hline Market growth & 3.42 & 3.55 & 1.00 \\
\hline Market span & 3.16 & 3.18 & 0.14 \\
\hline Product focus vs. service focus & 2.78 & 2.93 & 1.01 \\
\hline Geographical focus & 4.47 & 4.68 & $2.10^{*}$ \\
\hline Competition intensity & 4.26 & 4.35 & 0.68 \\
\hline Market concentration & 3.36 & 3.57 & 1.18 \\
\hline Easiness of market entry & 3.07 & 3.03 & -0.20 \\
\hline
\end{tabular}

Table 3. Differences in financial and manufacturing performance (only significant results displayed; $* \mathrm{p}<0.05$, ** $\mathrm{p}<0.01)$

\begin{tabular}{|l|c|c|c|}
\hline & $\begin{array}{c}\text { Inside-out } \\
\text { (average) }\end{array}$ & $\begin{array}{c}\text { Distributed } \\
\text { (average) }\end{array}$ & T-value \\
\hline Sales, absolute [USD] (A6a) & $90 \mathrm{M}$ & $600 \mathrm{M}$ & $2.51^{*}$ \\
\hline Sales, compared to competitors (A6i) & 3.31 & 3.63 & $2.39^{*}$ \\
\hline RoS, compared to competitors (A6m) & 3.03 & 3.40 & $2.39^{*}$ \\
\hline RoI, compared to competitors (A6n) & 4.47 & 4.68 & $2.69^{* *}$ \\
\hline Throughput time efficiency [\%] (B10a) & 51.55 & 36.20 & $-2.74^{* *}$ \\
\hline
\end{tabular}


Table 4. Differences in order winners (only significant results displayed; $* \mathrm{p}<0.05$ )

\begin{tabular}{|l|c|c|c|}
\hline & $\begin{array}{c}\text { Inside-out } \\
\text { (average) }\end{array}$ & $\begin{array}{c}\text { Distributed } \\
\text { (average) }\end{array}$ & T-value \\
\hline Product design and quality (A5ab) & 4.44 & 4.17 & $-2.51^{*}$ \\
\hline Customer service (A5af) & 3.83 & 4.09 & $1.95^{*}$ \\
\hline Product range (A5ag) & 3.27 & 3.56 & $1.99^{*}$ \\
\hline Frequent new products (A5ah) & 3.10 & 3.46 & $2.03^{*}$ \\
\hline Product innovation (A5ai) & 3.51 & 3.90 & $2.36^{*}$ \\
\hline
\end{tabular}

Table 5. Comparison of strategic priorities and strategic capabilities (only significant results displayed; ${ }^{*} \mathrm{p}<0.05$ )

\begin{tabular}{|l|c|c|c|}
\hline & $\begin{array}{c}\text { Inside-out } \\
\text { (average) }\end{array}$ & $\begin{array}{c}\text { Distributed } \\
\text { (average) }\end{array}$ & T-value \\
\hline Reducing time to market (B4f) & 3.80 & 4.13 & $2.29^{*}$ \\
\hline $\begin{array}{l}\text { Product customization ability } \\
\text { compared to 3 years ago (B9ac)) }\end{array}$ & 2.76 & 3.03 & $2.37^{*}$ \\
\hline $\begin{array}{l}\text { Capacity utilization compared to 3 } \\
\text { years ago (B9as) }\end{array}$ & 2.92 & 2.64 & $-2.14^{*}$ \\
\hline
\end{tabular}

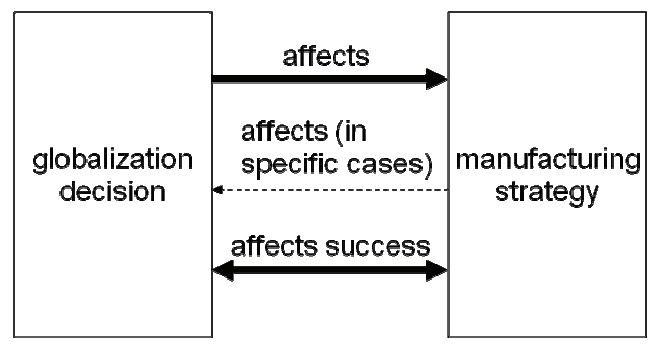

Figure 1. Conceptual linkages between globalization decision and manufacturing strategy

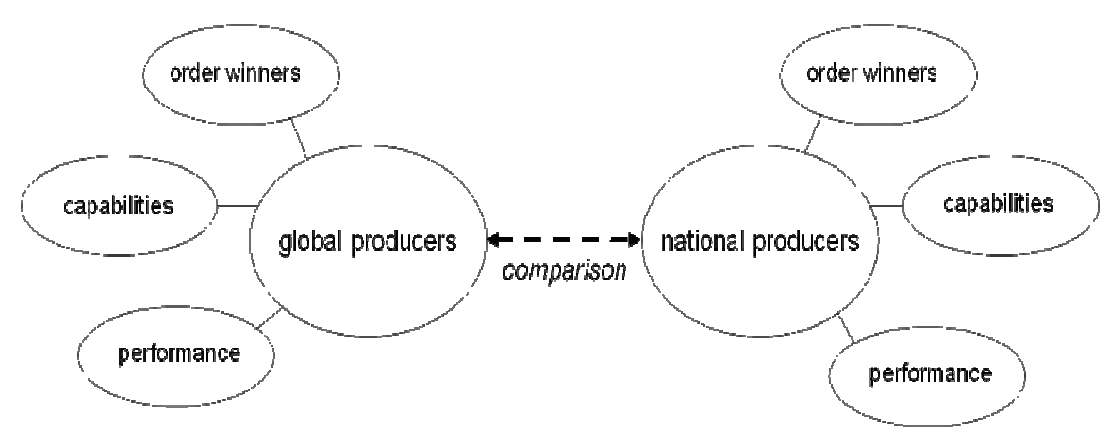

Figure 2. Research design 